\title{
Front Matter: Volume 9432
}

"Front Matter: Volume 9432," Proc. SPIE 9432, Behavior and Mechanics of Multifunctional Materials and Composites 2015, 943201 (20 May 2015); doi: 10.1117/12.2196304

SPIE Event: SPIE Smart Structures and Materials + Nondestructive Evaluation and Health Monitoring, 2015, San Diego, California, United States 


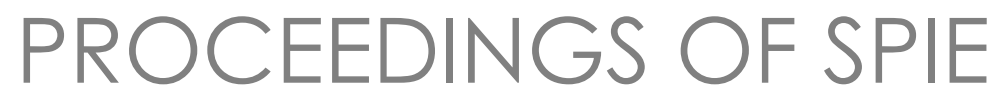

\title{
Behavior and Mechanics of Multifunctional Materials and Composites 2015
}

\author{
Nakhiah C. Goulbourne \\ Editor
}

9-11 March 2015

San Diego, California, United States

Sponsored by

SPIE

Cosponsored by

American Society of Mechanical Engineers (United States)

Cooperating Organizations

Intelligent Materials Forum (Japan)

Jet Propulsion Laboratory (United States)

National Science Foundation (United States)

Published by

SPIE 
The papers included in this volume were part of the technical conference cited on the cover and title page. Papers were selected and subject to review by the editors and conference program committee. Some conference presentations may not be available for publication. The papers published in these proceedings reflect the work and thoughts of the authors and are published herein as submitted. The publisher is not responsible for the validity of the information or for any outcomes resulting from reliance thereon.

Please use the following format to cite material from this book:

Author(s), "Title of Paper," in Behavior and Mechanics of Multifunctional Materials and Composites 2015, edited by Nakhiah C. Goulbourne, Proceedings of SPIE Vol. 9432 (SPIE, Bellingham, WA, 2015) Article CID Number.

ISSN: 0277-786X

ISBN: 9781628415353

Published by

SPIE

P.O. Box 10, Bellingham, Washington 98227-0010 USA

Telephone +1 3606763290 (Pacific Time) · Fax +1 3606471445

SPIE.org

Copyright (C) 2015, Society of Photo-Optical Instrumentation Engineers.

Copying of material in this book for internal or personal use, or for the internal or personal use of specific clients, beyond the fair use provisions granted by the U.S. Copyright Law is authorized by SPIE subject to payment of copying fees. The Transactional Reporting Service base fee for this volume is $\$ 18.00$ per article (or portion thereof), which should be paid directly to the Copyright Clearance Center (CCC), 222 Rosewood Drive, Danvers, MA 01923. Payment may also be made electronically through CCC Online at copyright.com. Other copying for republication, resale, advertising or promotion, or any form of systematic or multiple reproduction of any material in this book is prohibited except with permission in writing from the publisher. The CCC fee code is 0277-786X/15/\$18.00.

Printed in the United States of America.

Publication of record for individual papers is online in the SPIE Digital Library.

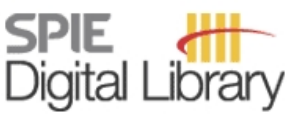

SPIEDigitalLibrary.org

Paper Numbering: Proceedings of SPIE follow an e-First publication model, with papers published first online and then in print. Papers are published as they are submitted and meet publication criteria. A unique citation identifier (CID) number is assigned to each article at the time of the first publication. Utilization of CIDs allows articles to be fully citable as soon as they are published online, and connects the same identifier to all online, print, and electronic versions of the publication. SPIE uses a six-digit CID article numbering system in which:

- The first four digits correspond to the SPIE volume number.

- The last two digits indicate publication order within the volume using a Base 36 numbering

system employing both numerals and letters. These two-number sets start with 00, 01, 02, 03, 04, $05,06,07,08,09,0 A, 0 B \ldots 0 Z$, followed by 10-1Z, 20-2Z, etc.

The CID Number appears on each page of the manuscript. The complete citation is used on the first page, and an abbreviated version on subsequent pages. 


\title{
Contents
}

\author{
vii Authors \\ ix Conference Committee
}

\section{SESSION 1 MECHANICS OF ACTIVE POLYMERS}

943202 Unifying relations in polymer photomechanics [9432-1]

943203 Thermoplastic polyurethane as a mechanochromic strain sensor [9432-2]

943204 A self-sensing fiber reinforced polymer composite using mechanophore-based smart polymer [9432-3]

\section{SESSION 2 PIEZOELECTRIC AND ELECTROSTRICTIVE MATERIALS}

943206 Electric field responsive origami structures using electrostriction-based active materials [9432-5]

943207 Characterization of lead zirconate titanate microwires using digital image correlation [9432-6]

943208 Effect of carbon nanotubes on properties of cement-sand-based piezoelectric composites [9432-7]

943209 Poly (vinylidene fluoride)/graphene nano-platelets electrically conductive composite foam for thermoelectric applications [9432-8]

\section{SESSION 3 CONSTITUTIVE BEHAVIOR OF PIEZOELECTRIC AND ACTIVE MATERIALS}

9432 OB Characterization and modeling time-dependent behavior in PZT fibers and active fiber composites [9432-10]

$94320 \mathrm{C}$ Uncertainty quantification in quantum informed ferroelectric phase field model [9432-11]

$9432 \mathrm{OE}$ Electromechanical analysis of tapered piezoelectric bimorph at high electric field [9432-13]

9432 OF Modeling and experimental characterization on fatigue behaviour of 1-3 piezocomposites [9432-14] 
9432 OG Molecular mechanics methods for individual carbon nanotubes and nanotube assemblies [9432-15]

$9432 \mathrm{OH} \quad$ Actuation-mechanisms of CNT-bucky papers and CNT-arrays [9432-16]

\section{SESSION 5 MATERIAL DEVELOPMENT AND CHARACTERIZATION}

9432 0J Dynamic characterization of Galfenol [9432-18]

9432 OK Modeling of thermo-mechanical fatigue and damage in shape memory alloy axial actuators [9432-19]

$9432 \mathrm{OL}$ Investigation of crystal structures of one-way shape memory Nitinol wire actuators for active steerable needle [9432-20]

\section{SESSION 6 SHAPE MEMORY POLYMER BEHAVIOR}

9432 OP Experimental characterization of a new class of polymeric-wire coiled transducers [9432-24]

$94320 Q \quad$ The effect of cross-linker concentration in the physical properties of shape memory gel [9432-25]

\section{SESSION 7 EXPERIMENTAL CHARACTERIZATION OF MULTIFUNCTIONAL COMPOSITES I}

9432 OR Effect of particle size on the properties of polyurea-based composites [9432-26]

9432 OS Self-response multi-functional composite material base on carbon nanotube paper using deicing, flame retardancy, thermal insulation, and lightning-strike protection [9432-27]

9432 OU Fabrication and characterization of polyaniline-graphene nanoplatelets composite electrode materials for hybrid supercapacitor applications [9432-36]

9432 OV Effects of interface treatment on the fatigue behaviour of shape memory alloy reinforced polymer composites [9432-40]

\section{SESSION 8 EXPERIMENTAL CHARACTERIZATION OF MULTIFUNCTIONAL COMPOSITES II}

9432 OW Power generation from base excitation of a Kevlar composite beam with ZnO nanowires [9432-29] 
$94320 Z$ Theoretical investigation of ionic effects in actuation and sensing of IPMCs of various geometries [9432-32]

$943210 \quad$ Ionic liquid based multifunctional double network gel [9432-33]

POSTER SESSION

943212 Effects of interface morphology and TGO thickness on residual stress of EB-PVD thermal barrier coatings [9432-35]

943214 Study of emissivity dependence upon concentration in CdTe quantum dots [9432-38]

943216 Mussel-inspired catecholamine polymers as new sizing agents for fiber-reinforced composites [9432-41] 
Proc. of SPIE Vol. $9432943201-6$

Downloaded From: https://www.spiedigitallibrary.org/conference-proceedings-of-spie on 26 Apr 2023 Terms of Use: https://www.spiedigitallibrary.org/terms-of-use 


\section{Authors}

Numbers in the index correspond to the last two digits of the six-digit citation identifier (CID) article numbering system used in Proceedings of SPIE. The first four digits reflect the volume number. Base 36 numbering is employed for the last two digits and indicates the order of articles within the volume. Numbers start with 00, 01, 02, 03, 04, 05, 06, 07, 08, 09, 0A, 0B...0Z, followed by 10-1Z, 20-2Z, etc.

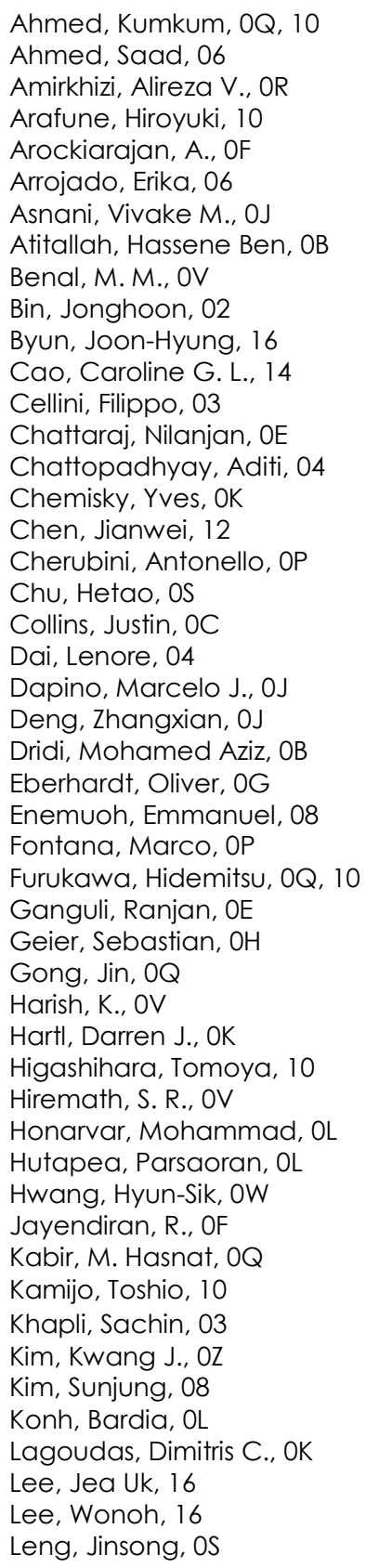

Liu, Yanju, OS

Liu, Yingtao, 04

Ma, Jian, 12

Mahapatra, D. Roy, OV

Mahrholz, Thorsten, $\mathrm{OH}$

Malakooti, Mohammad H., 07, OW

Martin, Matthieu, 14

Miller, Alexander T., 07

Mohan, Y., OF

Moretti, Giacomo, OP

Morinaga, Takashi, 10

Muliana, Anastasia, OB

Naguib, Hani E., 09, OU

Nelson, Shelby E., $\mathrm{OZ}$

Nemat-Nasser, Sia, OR

Oates, William S., 02, OC

Ounaies, Zoubeida, 06, OB

Palmre, Viljar, $\mathrm{OZ}$

Peterson, Sean D., 03

Porfiri, Maurizio, 03

Qiao, Jing, OR

Rinehart, Benjamin S., 14

Sato, Takaya, 10

Scheidler, Justin J., OJ

Shi, HaoTian Harvey, OU

Sigamani, Nirmal, 06

Sinapius, Michael, $\mathrm{OH}$

Sodano, Henry A., 07, OW

Stalbaum, Tyler, $0 Z$

Sun, Yu-Chen, 09

Terakita, Daryl, 09

Tseng, Alex C., 09

Vasireddi, Ramakrishna, OV

Vertechy, Rocco, OP

Wallmersperger, Thomas, OG

Wheeler, Robert W., OK

Wierach, Peter, $\mathrm{OH}$

Zhang, Zhichun, OS

Zhao, Ping, 08

Zhao, Yang, 12

Zou, Jin, 04 
Proc. of SPIE Vol. $9432943201-8$

Downloaded From: https://www.spiedigitallibrary.org/conference-proceedings-of-spie on 26 Apr 2023 Terms of Use: https://www.spiedigitallibrary.org/terms-of-use 


\section{Conference Committee}

Symposium Chairs

Victor Giurgiutiu, University of South Carolina (United States)

Christopher S. Lynch, University of California, Los Angeles

(United States)

Symposium Co-chairs

Jayanth N. Kudva, NextGen Aeronautics, Inc. (United States)

Theodoros E. Matikas, University of loannina (Greece)

Conference Chair

Nakhiah C. Goulbourne, University of Michigan (United States)

Conference Co-Chair

Hani E. Naguib, University of Toronto (Canada)

Conference Program Committee

Abhijit Bhattacharyya, University of Arkansas at Little Rock (United States)

Gregory P. Carman, University of California, Los Angeles (United States)

Pavel M. Chaplya, Sandia National Laboratories (United States) Constantin Ciocanel, Northern Arizona University (United States)

Marcelo J. Dapino, The Ohio State University (United States)

Sergio Luis dos Santos e Lucato, Teledyne Scientific Company (United States)

LeAnn E. Faidley, Wartburg College (United States)

Darren J. Hartl, Texas A\&M University (United States)

Daniel J. Inman, University of Michigan (United States)

Marc Kamlah, Karlsruher Institut für Technologie (Germany)

Haluk E. Karaca, University of Kentucky (United States)

Kwang Jin Kim, University of Nevada, Las Vegas (United States)

Dimitris C. Lagoudas, Texas A\&M University (United States)

Chad M. Landis, The University of Texas at Austin (United States)

Kam K. Leang, University of Nevada, Reno (United States)

Donald J. Leo, Virginia Polytechnic Institute and State University (United States)

Jiangyu Li, University of Washington (United States) 
Christopher S. Lynch, University of California, Los Angeles

(United States)

Karla M. Mossi, Virginia Commonwealth University (United States)

Robert C. O'Handley, Massachusetts Institute of Technology

(United States)

Zoubeida Ounaies, The Pennsylvania State University (United States)

Etienne Patoor, Universitè Metz (France)

Ralph C. Smith, North Carolina State University (United States)

Jonghwan Suhr, University of Delaware (United States)

Vishnu Baba Sundaresan, The Ohio State University (United States)

\section{Session Chairs}

1 Mechanics of Active Polymers

Nakhiah C. Goulbourne, University of Michigan (United States)

Hani E. Naguib, University of Toronto (Canada)

2 Piezoelectric and Electrostrictive Materials

Ralph C. Smith, North Carolina State University (United States)

William S. Oates, Florida State University (United States)

3 Constitutive Behavior of Piezoelectric and Active Materials

Zoubeida Ounaies, The Pennsylvania State University (United States)

Sebastian M. Geier, Deutsches Zentrum für Luft- und Raumfahrt e.V. (Germany)

4 CNTs and Nanostructured Materials

Marcelo J. Dapino, The Ohio State University (United States)

Alireza Vakil Amirkhizi, University of Massachusetts Lowell (United States)

5 Material Development and Characterization

Vishnu Baba Sundaresan, The Ohio State University (United States)

Jinsong Leng, Harbin Institute of Technology (China)

6 Shape Memory Polymer Behavior

Kwang Jin Kim, University of Nevada, Las Vegas (United States)

Hidemitsu Furukawa, Yamagata University (Japan)

7 Experimental Characterization of Multifunctional Composites I

Henry A. Sodano, University of Florida (United States)

Rocco Vertechy, Scuola Superiore Sant'Anna (Italy)

8 Experimental Characterization of Multifunctional Composites II

Darren J. Hartl, Texas A\&M University (United States) 
9 Ionic Polymers and Gels

Henry A. Sodano, University of Florida (United States)

Constantin Ciocanel, Northern Arizona University (United States)

Proc. of SPIE Vol. 9432 943201-11

Downloaded From: https://www.spiedigitallibrary.org/conference-proceedings-of-spie on 26 Apr 2023 Terms of Use: https://www.spiedigitallibrary.org/terms-of-use 
Proc. of SPIE Vol. 9432 943201-12

Downloaded From: https://www.spiedigitallibrary.org/conference-proceedings-of-spie on 26 Apr 2023 Terms of Use: https://www.spiedigitallibrary.org/terms-of-use 